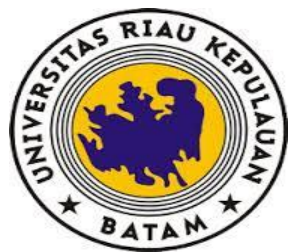

Available online at www.journal.unrika.ac.id

Jurnal KOPASTA

Jurnal KOPASTA, 4 (1), (2017) 22 - 27

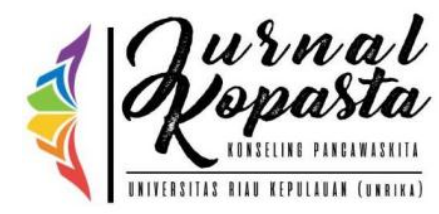

\title{
GAMBARAN PEMAHAMAN KONSEP DASAR MATEMATIKA SISWA DAN IMPLIKASINYA DALAM BIMBINGAN KONSELING
}

\author{
Septi Primakuria* \\ ${ }^{*}$ Division of Counseling and Guidance, University, of Riau Kepulauan, Batam
}

\begin{abstract}
Mathematics learning is the most difficult lesson which is considered by the students. This is because learning mathematics tends to require students to solve problems logically, creatively and critically. This study aims to see the basic concept of mathematics and the cooperation of BK teachers with subject teachers. This study used quantitative descriptive methodology with a sample of 30 students. And the Instruments of this study used Mathematics tests. From the test results obtained, in addition and reduction were 33.3\%; Multiplication and distribution were 26.67\%; Integers was 26.67\%; Fractions and decimal were 16.67\%; And algebra was $20 \%$.
\end{abstract}

\section{Keywords: Mathematics Concept}

\section{ABSTRAK}

Pembelajaran Matematika merupakan pelajaran yang dianggap sulit bagi siswa. Hal ini disebabkan belajar matematika cenderung mengharuskan siswa untuk memecahkan masalah secara logis, kreatif dan kritis. Penelitian ini bertujuan untuk melihat gambaran konsep dasar matematika dan kerjasama guru BK dengan guru mata pelajaran. Penelitian ini menggunakan metodologi deskriptif kuantitatif dengan sampel sebanyak 30 orang siswa. Instrumen yang diberikan berupa tes soal matematika. Dari hasil tes didapat, dalam penjumlahan dan pengurangan 33.3\%; perkalian dan pembagian $26.67 \%$; bilangan bulat $26.67 \%$; pecahan dan bilangan desimal $16.67 \%$; dan aljabar $20 \%$.

Kata Kunci: Konsep Dasar Matematika

\section{Pendahuluan}

Di sekolah ada banyak mata pelajaran yang harus ditempuh oleh siswa. Salah satu pelajaran yang wajib adalah pelajaran matematika. Adapun tujuan pembelajaran matematika adalah melatih cara berpikir secara sistematis, logis, kritis, kreatif dan konsisten (Depdiknas, 2004). Namun matematika merupakan pelajaran yang berat bagi siswa, hal ini karena kurangnya kemampuan dasar matematika siswa. Berdasarkan survey awal, dari 30 soal yang diberikan kepada 30 orang siswa didapat hasil; siswa masih belum hapal perkalian dasar, siswa belum memahami konsep bilangan bulat, siswa belum mampu menyelesaikan pecahan dan penjumlahan. Hal ini didukung dari hasil survey Program For International Student Assessment (PISA) yaitu kemampuan matematika siswa di Indonesia menduduki peringkat 64 dari 65

- Septi Primakuria

Email : septiprima1@gmail.com 
negara. Lebih lanjut Singgih Gunarsa (2004) kemampuan siswa kurang dalam bidang Matematika. Survey awal penelitian ini dimulai dari sharing guru mata pelajaran matematika kepada guru BK atas hasil belajar siswa yang tidak begitu maksimal. Melihat kondisi ini maka guru BK menyarankan kepada guru mata pelajaran untuk memberikan instrument berupa tes untuk melihat pemahaman siswa terhadap konsep dasar matematika. Adapun penelitian ini bertujuan untuk melihat gambaran konsep dasar matematika siswa dan implikasinya dalam Bimbingan Konseling.

\section{Metode Penelitian}

Metode penelitian merupakan cara untuk menyelesaikan masalah. Dalam penelitian ini menggunakan metode deskriptif kuantitatif. Deskriptif untuk menggambarkan masalah yang terjadi pada masa sekarang sebagaimana apa adanya. Populasi penelitian ini adalah MTs Bina Ummah dan yang menjadi sampel kelas 1 dan 2 yang terdiri dari 30 orang. Adapun instrumen yang digunakan adalah tes. Data diolah dengan teknik persentase.

\section{Hasil Penelitian}

Hasil penelitian dapat dilihat pada tabel 1 sebagai berikut:

Tabel 1. Hasil Tes Siswa

\begin{tabular}{|c|l|c|c|}
\hline No & \multicolumn{1}{|c|}{ Soal } & Benar & Persentase \\
\hline 1 & $\begin{array}{l}\text { Penjumlahan dan } \\
\text { pengurangan }\end{array}$ & 10 & $33,3 \%$ \\
\hline 2 & $\begin{array}{l}\text { perkalian dan } \\
\text { pembagian }\end{array}$ & 4 & $26.67 \%$ \\
\hline 3 & Bilangan bulat & 4 & $26.67 \%$ \\
\hline 4 & $\begin{array}{l}\text { Pecahan, bilangan } \\
\text { desimal }\end{array}$ & 5 & $16.67 \%$ \\
\hline 5 & Aljabar & 6 & $20 \%$ \\
\hline
\end{tabular}

Dari tabel 1 dapat dipaparkan bahwa untuk soal yang bentuk penjumlahan dan pengurangan dari 30 siswa yang benar hanya 10 orang dan yang salah ada 20 orang, jika dipersentasekan maka yang paham dengan soal penjumlahan dan pengurangan hanya $33.3 \%$. begitupun dengan soal perkalian dan pembagian, dari 30 orang siswa yang benar hanya 4 orang 
dan yang salah adalah 26 orang, jika dipersentasekan $26.67 \%$ yang benar dalam mengerjakan soal perkalian dan pembagian.

Lebih lanjut untuk soal bilangan bulat dari 30 orang siswa yang benar 4 orang dan yang salah adalah 26 orang, jika dipersentasekan $26.67 \%$. Soal pecahan dan bilangan decimal yang benar 5 orang dan yang salah 25 orang, jika dipersentasekan 16.67\%. Pada soal aljabar yang benar 6 orang dan yang salah ada 24 orang, jika dipersentasekan $20 \%$.

\section{Pembahasan}

Gambaran konsep dasar matematika siswa terlihat pada tabel 1. Dari tabel 1 maka dapat disimpulkan bahwa siswa kurang memahami konsep dasar. Hal ini tentu menjadi kendala bagi mereka dalam menyelesaikan soal. Untuk mengatasi hal ini tentu, guru matematika harus bekerja keras memberikan pemahaman ulang terhadap konsep dasar yang belum dikuasai oleh siswa dengan begitu maka siswa akan dapat mengikuti pelajaran yang lebih lanjut.

Berdasarkan data di atas maka guru mata pelajaran dapat berkolaborasi dengan guru BK untuk mereview kembali materi-materi yang belum duduk konsep dasarnya pada siswa. Agar lebih menarik maka dapat dilakukan dengan beberapa cara yaitu sebagai berikut;

1. Membentuk KKB (Kegiatan Kelompok Belajar)

a. Pengertian KKB

Kegiatan Kelompok Belajar (KKB) adalah pelayanan bimbingan belajar melalui kegiatan kelompok yang diarahkan kepada satu atau sejumlah kelompok siswa pada suatu sekolah yang menyelenggarakan kegiatan belajar bersama di luar jam pelajaran. Bimbingan Kegiatan Kelompok Belajar ini dipimpin oleh Guru Pembimbing bekerjasama dengan Wali Kelas, Guru Mata Pelajaran, Guru Praktik dan/atau pihakpihak lain yang terkait.

b. Tujuan KKB

Tujuan bimbingan Kegiatan Kelompok Belajar (KKB) adalah membantu para siswa mengembangkan berbagai potensi belajarnya secara optimal.

c. Bidang kegiatan KKB

Salah satu bidang dari KKB adalah berfokus pada penguasaan materi yaitu konsep dasar matematika dan keterampilan belajar yaitu cara menghapal perkalian serta kondisi pribadi siswa yaitu menanamkan suatu mindset pada siswa bahwa matematika itu mudah jika tahu "caranya". 
d. Pembentukan kelompok belajar

1. Jumlah anggota setiap kelompok berkisar 5-8 orang

2. Keanggotaan kelompok bersifat heterogen; yaitu dimungkinkan berhimpunnya ke dalam suatu kelompok siswa-siswa yang memiliki keragaman dalam kemampuan, jenis kelamin, dan status sosial-ekonomi.

3. Memperhatikan hasil analisis sosiometri, artinya para peserta sedapat-dapatnya saling menyenangi satu sama lain.

4. Kegiatan dalam kelompok belajar terdiri atas;

- Mendalami materi pelajaran sehari-hari

- $\quad$ Menyelesaikan tugas kelompok yang diberikan oleh guru

- $\quad$ Menanggulangi kesulitan belajar yang dialami anggota kelompok

- Mempersiapkan diri untuk ulangan atau ujian

- Menindaklanjuti hasil ulangan, ujian atau tugas-tugas

e. Pelaksana KKB terdiri atas;

- Guru BK

- Guru mata Pelajaran

- Siswa yang belum menguasai konsep dasar matematika

2. Bkp (Bimbingan Kelompok)

a. Pengertian Bimbingan Kelompok

Menurut Prayitno (2012:149) layanan bimbingan kelompok adalah suatu kegiatan yang mengaktifkan dinamika kelompok untuk membahas berbagai hal yang berguna bagi pengembangan pribadi yang menjadi peserta kegiatan kelompok

b. Tujuan Bimbingan Kelompok

Bimbingan kelompok betujuan untuk membantu para siswa yang mengalami masalah melalui prosedur kelompok.

c. Fungsi Bimbingan Kelompok

Menurut Dewa Ketut Sukardi (2000:48) layanan bimbingan kelompok mempunyai tiga fungsi yaitu: (1) fungsi informatif, (2) fungsi pengembangan, (3) fungsi preventif dan kreatif. Fungsi pertama dan kedua dilaksanakan melalui kegiatan Home Room, sedangkan fungsi ketiga, digunakan untuk keperluan terapi masalah-masalah psikologi

d. Tahap-tahap Pelaksanaan Bimbingan Kelompok 
Prayitno (2012:172) mengemukakan empat tahapan bimbingan kelompok, yaitu: tahap pembentukan, tahap peralihan, tahap kegiatan, tahap penyimpulan, dan tahap pengakhiran.

\section{Layanan Penguasaan Konten}

a. Pengertian layanan penguasaan konten

Layanan penguasaan konten adalah layanan bantuan pada siswa (baik secara individu maupun berkelompok) untuk menguasai kemampuan atau kompetensi tertentu melalui kegiatan belajar.

b. Tujuan layanan penguasaan konten

Prayitno (2004) tujuan layanan penguasaan konten adalah dikuasainya konten tertentu oleh siswa.

c. Fungsi layanan penguasaan konten

Mugiarso (2009) fungsi layanan penguasaan konten terdiri atas fungsi pengembangan dan pemeliharaan pada siswa secara mantap, terarah dan berkelanjutan.

d. Komponen dalam layanan penguasaan konten

Prayitno (2004) menjelaskan komponen layanan penguasaan konten terdiri atas;

1) Konselor

2) Siswa

3) Konten

Pemberian materi konsep dasar matematika dengan tiga hal ini tentu dapat berjalan jika ada kerjasama antara guru mata pelajaran dan guru BK. Melalui kegiatan ini konsep dasar yang belum dipahami dapat ditingkatkan.

\section{Penutup}

Matematika merupakan pelajaran yang dianggap sulit oleh siswa. Rendahnya hasil belajar siswa salah satunya disebabkan oleh karena kemampuan siswa yang kurang. Hal ini disebabkan oleh pemahaman terhadap konsep dasar matematika yang rendah seperti perkalian, penjumlahan, pecahan dan aljabar. Menyingkapi hal ini maka guru Bimbingan konseling dan guru mata pelajaran bekerja sama untuk membantu siswa dengan melakukan beberapa kegiatan. 


\section{Daftar Pustaka}

Dewa Ketut Sukardi. 2003. Pengantar Pelaksanaan Program Bimbingan dan Konseling di Sekolah. Jakarta: Renekacipta

Heru Mugiharso. 2009. Bimbingan dan Konseling. Semarang: Unnes Pres.

Prayitno. 2012. Jenis Layanan dan Kegiatan Pendukung Konseling. Padang: Program PPK Jurusan BK UNP.

Singgih D. Gunarsa. 2004. Psikologi Perkembangan Anak dan Remaja. Jakarta : Gunung Mulia 